\title{
Plays and Poems
}

These are of only minor interest. For details of editions, see p. 313. Complete Plays and Selected Poems of Charles Dickens (London: Vision Press, 1970) includes the texts of six plays: The Strange Gentleman, The Village Coquettes, Is She his Wife?, The Lamplighter, Mr Nightingale's Diary (written jointly with Mark Lemon), and No Thoroughfare (jointly with Wilkie Collins). This is in no sense a scholarly edition. 